\title{
Fighting against the Wind: Politics of 'The Local' and Corporate Othering in Community Activism against Wind Energy Installation in Upstate New York
}

\author{
Marissa Sonnis-Bell
}

\begin{abstract}
There is an emerging local community movement in rural upstate New York against Apex, a renewable energy company seeking to capitalize on wind energy. This chapter focuses on how the socio-political processes of constructing the 'local' and the 'other' interplay with these politics of resistance. At the heart of this process is Save Ontario Shores, a citizen coalition imbued with a sense of community predominantly conjured in response to this external threat. Two dominant processes involving strategic external othering are the struggle between conflicting objectives of New York state-level and local-level governance, and the construction of Apex as an inhuman and corporate outsider fixated on capital gains. The relative and shifting nature of 'the local' plays a major role in defining what the community supports and what it does not. However, the resulting concept of 'local' is not homogeneous, and has resulted in the alienation of some residents who are in support or simply not opposed to Apex. Ultimately, what is at stake is not just wind energy installation, but identity and representation of the 'local'.
\end{abstract}

\section{Keywords}

wind energy - opposition to wind - othering - local/non-local - community activism - procedural justice - corporate othering 
In the small, quiet, rural towns of Somerset and Yates in upstate New York, residents have been deeply involved in fighting against a proposed 200-megawatt wind energy project. This project, named Lighthouse Wind, is proposed by Apex, a renewable energy company hoping to capitalize on local wind resource and a well-established power grid infrastructure on Lake Ontario shores. ${ }^{1}$ The driving force behind the opposition is Save Ontario Shores, named in reference to the letters sos, a self-organized citizen coalition of local resident 'wind warriors' from towns of Somerset and Yates. ${ }^{2}$ Community opposition to wind energy development projects has been thoroughly documented, from Pasqualetti examining wind opposition across multiple national contexts, ${ }^{3}$ to Devine-Wright's examination of opposition to wind energy beyond NIMBYism. ${ }^{4}$ While some similarities to other case studies can be found, this chapter is less concerned with examining the intricacies of factors affecting perception in yet another case study of wind energy opposition. Instead, I focus only on two interrelated processes specific to this case study. First, I examine the strategic construction of the 'other' and production of external threats central to opposing the wind energy project. Second, I seek to elucidate how notions of 'community' and 'the local' are conjured specifically in response to this external 'other', and are pivotal to the successful opposition campaigns of sos. This chapter therefore focuses on how the socio-political processes of constructing the 'local' and the 'other' interplay with politics of resistance against this wind energy initiative. To this goal, this chapter draws from preliminary research combining primary and secondary sources, participatory observation, informational conservations, municipality surveys, public comments, newspaper articles, and archived public documents.

This chapter will proceed as follows: first, I examine processes of strategic othering in which the objectives of state-level governance are seen to conflict with those of local-level governance; second, I explore the notion of corporate othering. Third, I focus on upstate/downstate tensions constructing the 'local';

1 'About Lighthouse', Apex, Viewed on 14 May 2016, http://www.lighthousewind.com/about _lighthouse/.

2 'Homepage', Save Ontario Shores, Viewed on 14 May 2016, http://lakeontarioturbines.com/.

3 Martin J. Pasqualetti, 'Opposing Wind Energy Landscapes: A Search for Common Cause', Annals of the Association of American Geographers 101.4 (2011): 907-917.

4 Patrick Devine-Wright, 'Beyond NIMBYism: Towards an Integrated Framework for Understanding Public Perceptions of Wind Energy', Wind Energy 8 (2005): 125-139. 
and fourth, I explore how othering constructs a problematic 'local' drawn upon in opposing Lighthouse Wind.

\section{The Neoliberal Contradictions of Multi-Level Governance: Conflicting State/Local Objectives}

The first of the dominant processes at play involving strategic external othering is the struggle between the conflicting objectives of New York state-level and local-level governance that has facilitated a stronger definition, if not creation, of the 'local', since the formation of the citizen coalition was directly in response to a local governance framework deemed inadequate to serve 'local' needs. Neoliberal trends in governance have been characterized by a devolution of governance to lower levels, for example, from national to provincial, or provincial to municipal. ${ }^{5}$ However, the case of renewable energy project legislation in New York State contradicts this and points to the struggle between conflicting objectives. At the heart of this struggle is the New York State 'Article 10'. Within the legal framework of Article 10, the state can intervene and override local town 'home rule' decision-making in the case of energy projects larger than $25 \mathrm{MW}$, when the state feels that such projects are within the best interest of broader strategic renewable energy goals. ${ }^{6}$ These 'simplified state-level siting and permitting procedures that minimize opportunities for local opposition show a statistical advantage in wind energy development', although they also tend to increase local opposition due to lack of community input. ${ }^{7}$ Figure 7.1. shows a local protest sign designed and printed by Save Ontario Shores which reads "Gov. Cuomo: Return Local Control", addressed to the Governor of New York State Andrew Cuomo. It is a direct reference to the power imbalance created by the Article 10 process which shifts the control away from local municipalities toward New York State.

Similar frameworks are in place just across the border in the Province of Ontario, Canada. In the Canadian case, recent studies suggest that this struggle of local vs. non-local government interests can be a determining factor in whether a community opposes wind energy development. Walker found that

5 Martin Jones, Mark Goodwin, and Rhys Jones, 'State Modernization, Devolution and Economic Governance: An Introduction and Guide to the Debate', Regional Studies 39A (2006): 397.

6 'Article 10 Law', Department of Public Service, Viewed 16 May 2016, http://www3.dps.ny.gov/ W/PSCWeb.nsf/All/D12Eo78BF7A746FF85257A70004EF402?OpenDocument/.

7 Christiane Bohn and Christopher Lant, 'Welcoming the Wind? Determinants of Wind Power Development among U.S. States', The Professional Geographer 61.1 (2009): 87. 


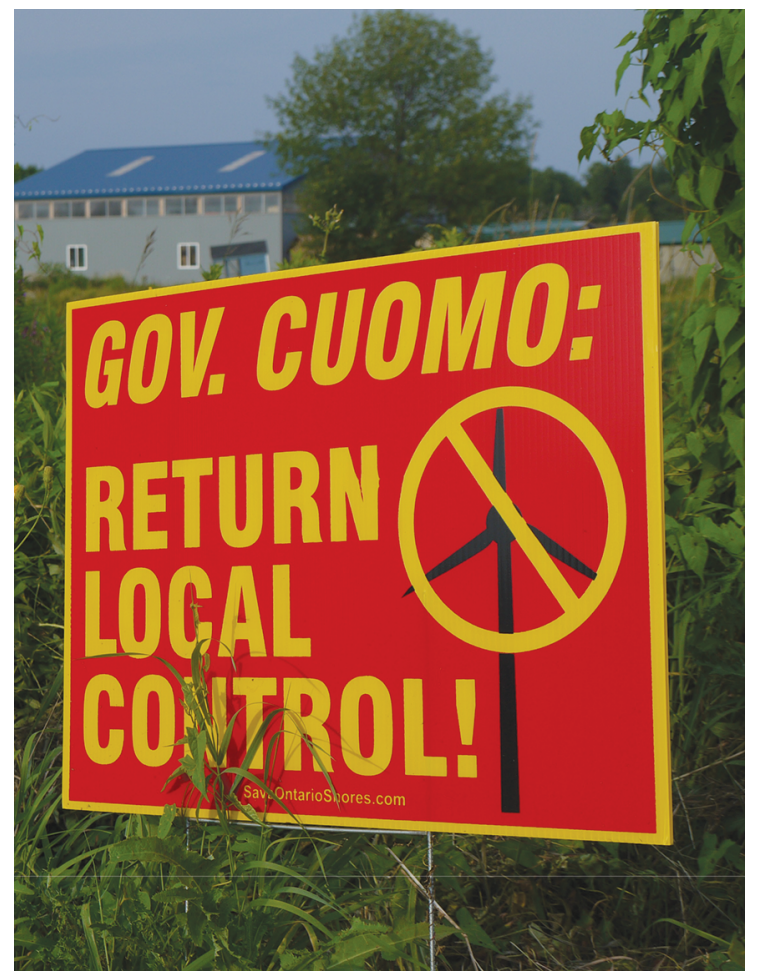

FIGURE 7.1 Local sos protest sign, with a farm in the background in Orleans County, New York PHOTOGRAPH COURTESY OF AUTHOR

communities in Ontario, where the state controlled decision-making, opposed wind energy projects; while in contrast, communities in Quebec were entirely unconcerned and in fact highly supportive of community-based wind energy projects where the community led the projects. ${ }^{8}$ Therefore, whether wind energy decision-making is governed by local municipalities or state-level authorities can hugely impact project outcomes and social acceptability.

The governance mechanisms for energy projects are an issue of procedural legitimacy, which is the extent to which local residents and local governments are involved in decision-making, something that the New York State Article 10 process can inhibit. The Article 10 process does have space for public input, however, the final decision ultimately lies with a state-appointed siting board. Bohn and Lant, when comparing across U.S. states, found a distinct pattern that

8 Chad Walker, “"By the Time Neighbours Find Out, It's a Sure Thing!” Wind Energy and Procedural Justice in Canada' (Paper presented at the annual meeting for the American Association of Geographers, San Francisco, California, March 29 - April 2, 2016). 
'local opposition can occur if the public questions the procedural legitimacy of locational decision-making for individual projects. ${ }^{9}$ The issue of procedural legitimacy is evidently on the minds of the local residents and representatives of Somerset and Yates who oppose the proposed wind project. Exemplifying such a view is a comment submitted to the Somerset Town survey, which states: 'We pay taxes on our land, but the State can "overrule" . ${ }^{10}$ Meanwhile, representatives of the township have also been

'critical of the loss of home rule on the project, with the final decision on land use made by the state instead of a local board as part of a new Article 10 process.'11

It is clear that local residents and local government officials are unhappy with the conflicting interests of New York State and local Townships and therefore view it as an external threat to their 'local sovereignty'. This is a separate concern from the corporate 'other', in this case Apex, although the corporate and government 'other' often appear interlinked in the minds of local residents. In the following section I elaborate on what I mean by the 'corporate other'. the Context of Perceived Benefits

The second process of othering relates to an emphasis on the financial interests of Apex and perceived benefits to the community. These help frame Apex as an inhuman and corporate outsider fixated on capital gains, aided by the fact that Apex is a large, profitable, multi-state corporation that operates across 25 states and is headquartered in Virginia. As emphasized by the words of sos, Apex is 'an out-of-state corporation that has the potential to gain enormous profits.' ${ }^{2}$ The benefits are perceived by the local community to flow outside of the area, or at the very least be limited. This lack of perceived benefits has also played a role in other cases of opposition to wind energy in Cape Cod,

$9 \quad$ Christiane Bohn and Christopher Lant, 'Welcoming the Wind', 98.

10 'Wind Energy Project Survey Comments', Town of Somerset, Viewed on 14 May 2016, http:// www.somersetny.org/home/pages/wind-energy-project-survey-comments.

11 Tom Rivers, 'Assembly Leader Fails to Nominate Local Resident for Turbine Siting Board'. Orleans Hub, January 22, 2016, Viewed on 5 February 2016, http://www.orleanshub.com/ news2016/Assembly-leader-fails-to-nominate-local-resident-for-turbine-siting-board.htm/. 
Massachusetts, and Lewis Isle, Scotland, as documented by Pasqualetti. ${ }^{13}$ Residents in this case have raised concerns in the Somerset town survey referencing the 'non-local' and corporate nature of Apex, as well as hinting at concerns over procedural legitimacy and community involvement:

This household supports alternative non-industrial, non-centralized energy development ... Inviting large, non-local companies to come in and 'develop' in this town is a recipe for disaster ... Please use your energy and influence to support community businesses and residents rather than corporations and politicians that have no true stake in living here. ${ }^{14}$

This comment speaks to three issues discussed in this chapter, the first issue of state-level government 'politicians' inadequate in serving local needs. Second, the notion of an external corporation with external interests playing on the local/non-local divide; and third, the issue of procedural legitimacy and role of local community in decision making.

Based upon the issues of multi-level conflicting interests of government and corporations, comments and feelings become emotionally charged and influence how the benefits of the project are perceived. Whether or not there are actual benefits to the local community becomes irrelevant when they are not perceived by local residents. Glenn Maid, a representative of sos speaks to this in their comments on Lighthouse Wind with the belief that there will be no benefits:

This is nothing but an unholy alliance between government and large corporations. Misleading promises give wind energy neighbors (sic) the impression that tax money and utility benefits will be enjoyed, but be wary. That does not happen. ${ }^{15}$

While it is clear that the lack of perceived local benefits plays some role in the social acceptability of this particular proposed wind energy project, it is not clear whether real benefits to the community would be a determining factor in social acceptability. Instead, it is possible that the 'corporate otherness' of

\footnotetext{
13 Pasqualetti, 'Opposing Wind Energy Landscapes', 907-917.

14 'Wind Energy Project Survey', Town of Somerset.

15 Max Warfield, 'Anti-Turbine Crowd Weighs in on Lighthouse Wind', Lockport Journal, May 1, 2015, Viewed on 16 May 2016, http://www.lockportjournal.com/news/local_news/ anti-turbine-crowd-weighs-in-on-lighthouse-wind/article_o1ogfb91-24a5-5a81-b823 -689 cd61ifib7.html.
} 


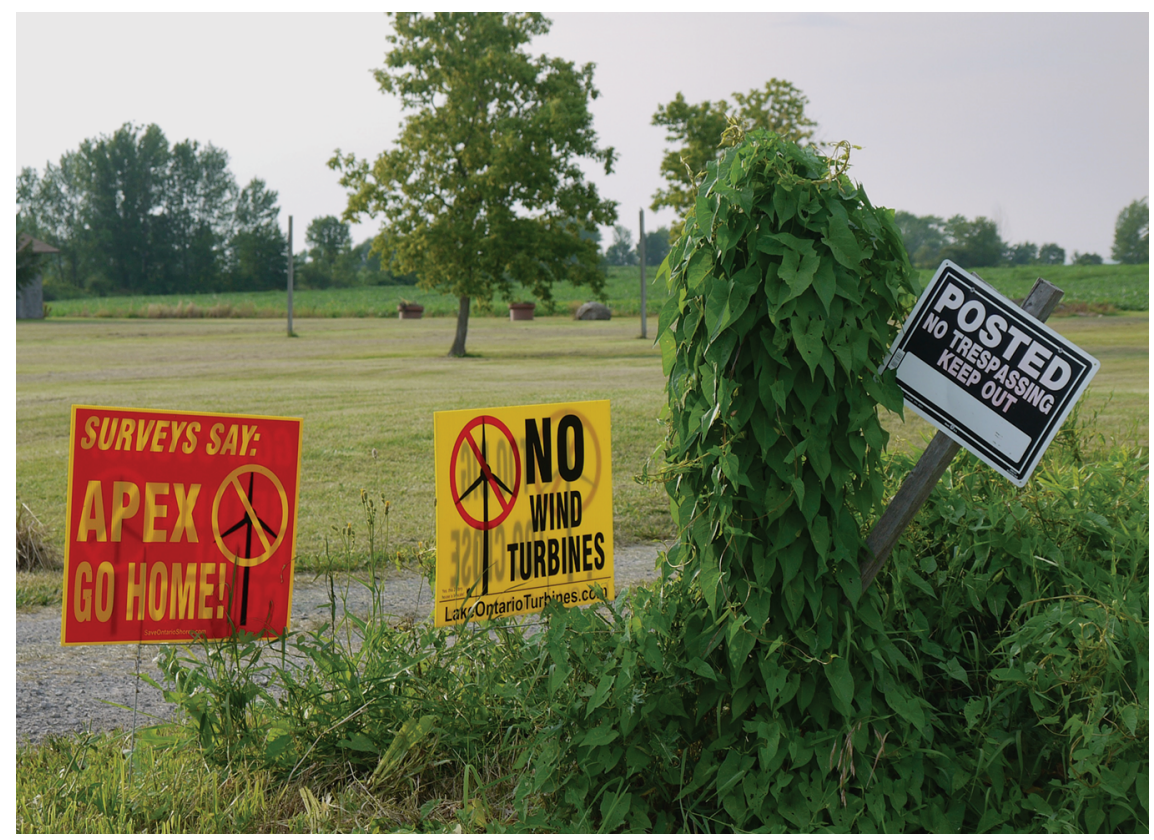

FIGURE 7.2 SOS protest signs by the roadside on private property in Orleans County, New York PHOTOGRAPH COURTESY OF AUTHOR

Apex is a much more significant driving force of opposition. In support of this, another comment states the following: 'Any monetary payment receive (sic) would be like selling our souls to the devil. ${ }^{16}$ This suggests that even if there were benefits to the community, the fact that the corporations are outsiders with non-local interests is what drives opposition. Figure 7.2. shows again local sos protest signs, specifically the sign on the left of the image reads: "Surveys say: Apex go home!", illustrating a direct message to the Apex corporation referencing that it is not a local organization, rather its "home" is based elsewhere, in this case Virginia. Seems to Be the Only Place that Benefits'

Wrapped up in the perceived benefits to the immediate local area are historic upstate/downstate core-periphery tensions. Namely, peripheral, rural, marginal

16 'Wind Energy Project Survey', Town of Somerset. 
areas such as upstate New York often become sites of production to be exploited for the benefit of downstate resource and energy demands of urban cores such as New York City, approximately 400 miles away from Yates and Somerset. At numerous public meetings, members of sos have stated that if New York City needs electricity 'they should put the turbines in their back yard. ${ }^{17}$ Other cases of wind opposition have had similar themes. For example, opposition to wind energy development in Catalonia, Spain, is also tied to core-periphery dynamics of rural areas being exploited for the benefit of cores such as Barcelona. ${ }^{18}$ Along with this are the problematics of power imbalances, and the oftenexternal nature of multinational corporations with external interests and lack of perceived local benefits.

In the Lighthouse Wind case, the boundary between the local and nonlocal is clear and based upon existing scalar politics. The local includes the towns and even counties but beyond this, the distant counties and cities of downstate are not included within this 'local'. A comment in the Town of Somerset Survey touches on these themes in exclaiming the following: 'Town of Somerset residents will not see any benefit from the turbines, not in tax reduction or electrical cost! It still all goes downstate and always will!'19 This quote in particular draws upon these historic core-periphery relations. This is not just about New York City requiring electricity; this is about a historic relationship of exploitation of resources in upstate New York. Another comment explains an underlying perception of inequality: 'NYC seems to be the only place that benefits - Cheap electricity goes right by our homes to "the big city!"' ${ }^{20}$ The electricity generated could provide benefits to the local community in terms of reduced rates, but instead is perceived to flow directly past them to downstate.

These processes of state, corporate and downstate (non-local) 'othering' all manifest in dichotomous othering producing a clear 'other'. At the same time, however, the creation of an 'other' enables a clearer definition of the 'self', in this case allowing for the construction of a 'community' and a 'local', enabling a stronger position from which to oppose the Lighthouse Wind project. In the following section, I delve into this construction of 'local' in response to an external threat.

\footnotetext{
17 Stated by a resident of Yates at a Yates Town Board Meeting, 10 March 2016.

18 Jaume Franquesa, Power Struggles: Dignity, Value, and the Renewable Energy Frontier in Spain (Bloomington: Indiana University Press, 2018), 10.

19 'Wind Energy Project Survey', Town of Somerset.

$20 \quad$ 'Wind Energy Project Survey Comments', Town of Somerset.
} 

Response to an External Threat

Save Ontario Shores, the local citizen coalition driving opposition has been very active in its opposition campaign and has had some successes. sos calls upon its members to be present and be vocal at public Town Board meetings. They have also conducted surveys of public opinion, and count among their successes pressuring Apex to sign a code of conduct, and a modification of a local wind energy zoning ordinances making it significantly more difficult to place wind turbines within the bounds of Somerset and Yates. ${ }^{21,22}$ It is not clear whether the opposition would be as strong if it were not for this organized and persuasive campaign of opposition. A 2007 survey in the Town of Yates found an overwhelming majority of 70\% strongly in favour of the Town encouraging 'wind energy facilities to locate in the Town of Yates', 23 and it is unclear why exactly the opinion shifted following the introduction of Lighthouse Wind.

More importantly, sos has partaken in the othering of government and corporate interests in garnering support for its campaign of opposition. In conjunction with this, sos also draws upon the concept of the 'local' and conjures a sense of community and solidarity predominantly constructed only in response to the external threat. This relative and shifting nature of 'the local' plays a major role in defining what the community supports and what it does not. However, the resulting concept of 'local' is not homogeneous, and has simultaneously resulted in the alienation of some residents who are in support or simply do not oppose the wind turbine installation.

One way in which the 'local' is defined by sos is in terms of who resides in the area, which comes with its contradictions. In general, the concept of the 'local' is known to be a vague and ambiguous term that shifts based on scale of analysis and intentional scalar politics. ${ }^{24}$ When Apex invited union members from neighbouring Lockport to attend a Town Board meeting in support of Lighthouse Wind and the jobs it would provide, sos members were infuriated

21 Kaley Lynch, 'Somerset Amends Wind Energy Zoning Law' Lockport Journal, February 24, 2016, Viewed on 4 June 2016, http://www.lockportjournal.com/news/local _news/somerset-amends-wind-energy-zoning-law/article_e84e3f95-164a-5d13-9ofc -ac239e198eod.html/.

22 'Local Law Filing', Town of Yates, Viewed on 25 May 2016, http://townofyates.org/ LegalNotices/2016/14056001_1\%2ofinal.pdf/.

23 '2007 Town of Yates Survey Results for Wind Farms in the Town', Town of Yates, Viewed on 4 June 2016, http://www.townofyates.org/Extras/Wind\%2oEnergy\%2osurvey.htm/.

24 Andrew Herod, Scale (London: Routledge, 2011), 27. 
that 'Apex filled the room with outsiders who had no place being there.25 However, at the same time they encourage local residents and their friends and families (regardless of place of residence) to write letters to the Public Service Commission in opposition to the project. sos also draws upon a large network of supporters across the U.S. mainly through social media, and yet their website emphasizes that sos is supported only by 'local donations.' ${ }^{26}$ Furthermore, a large number of those opposed to the wind turbines are self-proclaimed 'snowbirds', those whom live half the year in Florida or similar warm-weather places and half the year in lake-view vacation homes on the shore of Lake Ontario. This evidently qualifies these 'snowbirds' within the bounds of the sos defined 'local' (given that members of the board are 'snowbirds' themselves); given some ownership of property in the area. Others mentioned having a dominant residence within other nearby municipalities but owning land, which again might qualify them as 'local'. In contrast, some residents felt they could not vote and could not weigh in on the wind energy debate in the area specifically because they could not count themselves as local. ${ }^{27}$

The creation of this community of support is also founded on vague terms. While the community nature of this grassroots organization is emphasized, sos board members openly discuss that they did not know each other and did not know their neighbours with whom they now work in sos, prior to the Lighthouse Wind proposal. Furthermore, the 'local' that is produced excludes residents of the Towns of Somerset and Yates who do not voice opposition to sos and one is almost seen as a traitor to the 'local' if one either signs a lease or voices support for Apex. In other scenarios, these residents in support of Apex are seen to have been deceived by Apex.

Overall, what can be preliminarily concluded here is that the 'local' plays a role in defining what the community supports and what it does not. However, the concept is ambiguous, relative, shifting and not homogeneous. It has simultaneously resulted in the alienation of some residents who are in support or simply not opposed to the wind turbine installation.

To complement existing studies of opposition to wind energy projects, I chose to focus on how the process of othering and externalization has contributed

\footnotetext{
25 Personal Communication with Somerset resident.

26 'Homepage', Save Ontario Shores.

27 Personal communication with Yates resident.
} 
to local opposition to wind. The processes of othering are framed in terms of multiple dichotomies: local/state, community/corporate, and local/non-local. This research also adds to a growing literature on the role of procedural legitimacy in affecting social acceptability of wind energy projects, in terms of understanding how lack of procedural legitimacy can be a determining factor in making a project less acceptable.

I also argue that the othering, both of the external threat of Apex and the external benefits perceived to be enjoyed by Apex, has successfully produced a strong sense of 'local' that has been strategically utilized by sos to successful effect of battling the proposed Apex Lighthouse Wind project. This notion of 'local' only arose in direct response to this external threat. The impact of perceived benefits interplays with concepts of the 'local' in two ways, by judging the benefits or lack thereof felt by the 'local' community, and in creating an 'other' deemed to be the primary recipient of the benefits in the form of 'profit' and 'corporate gain'. These contributions are useful and significant in the wake of the ever-increasing risks of climate change, growing awareness of its anthropogenic origin, and thus a growing need for clean and renewable energy.

While some locals declare themselves to be environmentally conscious, particularly in regards to the environmental concerns of the wind turbines, many residents of this area (predominantly white, older, retired, and mostly politically conservative and Republican), feel that climate change is not a concern, is not of anthropogenic origin, or believe the effects of climate change to be geographically distant. Therefore, moral obligations of persuasion to host wind turbines are unlikely to be of any effect. Rather a focus on local perceived benefits and community involvement, either through investiture or community participation in decision-making, are likely to be more effective in pushing through successful wind energy projects. Finally, what this means for notions of the 'local' is a reaffirmation of existing theories of the fluidity and political flexibility of what it means to be 'local. ${ }^{28}$

\section{Bibliography}

'2007 Town of Yates Survey Results for Wind Farms in the Town'. Town of Yates. Viewed on 4 June 2016. http://www.townofyates.org/Extras/Wind\%2oEnergy\%2osurvey .htm/.

28 Patrick Devine-Wright and Bouke Wiersma, 'Opening up the "Local" to Analysis: Exploring the Spatiality of UK Urban Decentralised Energy Initiatives', Local Environment 18.10 (2013): 1101. 
'About Lighthouse'. Apex. Viewed on 14 May 2016. http://www.lighthousewind.com/ about_lighthouse/.

Bohn, Christiane and Christopher Lant. 'Welcoming the Wind? Determinants of Wind Power Development among U.S. States'. The Professional Geographer 61.1 (2009): 87-100.

Devine-Wright, Patrick. 'Beyond NIMBYism: Towards an Integrated Framework for Understanding Public Perceptions of Wind Energy'. Wind Energy 8 (2005): 125-139.

Devine-Wright, Patrick and Bouke Wiersma. 'Opening up the "Local" to Analysis: Eexploring the Spatiality of UK Urban Decentralised Energy Initiatives'. Local Environment 18.10 (2013): 1099-1116.

Franquesa, Jaume. Power Struggles: Dignity, Value, and the Renewable Energy Frontier in Spain. Bloomington: Indiana University Press, 2018.

Herod, Andrew. Scale. London: Routledge, 2011.

Jones, Martin, Mark Goodwin, and Rhys Jones. 'State Modernization, Devolution and Economic Governance: An Introduction and Guide to the Debate'. Regional Studies 39A (2006): 397-403.

'Local Law Filing'. Town of Yates. Viewed on 4 June 2016. http://townofyates.org/ LegalNotices/2016/14056001_1\%2ofinal.pdf/.

Lynch, Kaley. 'Somerset Amends Wind Energy Zoning Law'. Lockport Journal, 24 February 2016. Viewed on 4 June 2016. http://www.lockportjournal.com/news/local _news/somerset-amends-wind-energy-zoning-law/article_e84e3f95-164a-5d13 -gofc-ac239e198eod.html/.

Pasqualetti, Martin J. 'Opposing Wind Energy Landscapes: A Search for Common Cause'. Annals of the Association of American Geographers 101.4 (2011): 907-917.

Rivers, Tom. 'Assembly Leader Fails to Nominate Local Resident for Turbine Siting Board'. Orleans Hub, 22 January 2016. Viewed on 5 February 2016. http://www .orleanshub.com/news2016/Assembly-leader-fails-to-nominate-local-resident-for -turbine-siting-board.htm/.

Walker, Chad. ' "By the Time Neighbours Find Out, It's a Sure Thing!” Wind Energy and Procedural Justice in Canada'. Paper presented at the annual meeting for the American Association of Geographers, San Francisco, California, March 29-April 2, 2016.

Warfield, Max. 'Anti-Turbine Crowd Weighs in on Lighthouse Wind'. Lockport Journal. May 1, 2015. Viewed on 16 May 2016.

http://www.lockportjournal.com/news/local_news/anti-turbine-crowd-weighs-in-on -lighthouse-wind/article_o1ogfb91-24a5-5a81-b823-689cd611fib7.html/.

'Wind Energy Project Survey Comments'. Town of Somerset. Viewed on 14 May 2016. http://www.somersetny.org/home/pages/wind-energy-project-survey-comments. 